\title{
High expression of miR-214 is associated with a worse disease-specific survival of the triple-negative breast cancer patients
}

 \\ and Edvīns Miklaševičs ${ }^{1}$
}

\begin{abstract}
Background: Hereditary triple-negative breast cancer patients have better recurrence-free survival than triplenegative sporadic ones. High expression of some of the miRNAs is related to worse overall and disease-free survival of triple-negative breast cancer patients. The attempt to associate expression level of some miRNA in triple-negative hereditary and sporadic breast cancers to disease specific survival was performed in this study.

Material and methods: Study group was made of 18 triple-negative breast cancer patients harboring the BRCA1 gene mutations and 32 triple-negative sporadic breast cancer patients. Quantitative amount of mir-10b, mir-21, mir-29a, mir-31, and mir-214 by real-time PCR was assessed. The disease-specific survival in relation of high and low levels of some of the miRNAs was analyzed using Log-rank (Mantel-Cox) test.

Results: MiR-214 showed significantly higher expression level in sporadic tissues than in hereditary ones $(p=0.0005)$. Triple-negative breast cancer patients with high level of miR-214 showed significantly worse disease-specific survival than patients with low level $(p=0.0314)$.
\end{abstract}

Conclusions: Our finding suggests that miR-214 possibly could be used as a potential prognostic biomarker for triple-negative breast cancer patients.

Keywords: MiRNA expressionm, Hereditary and sporadic breast cancers, Triple-negative subtype

\section{Background}

Breast cancer is the most wide spread tumor among women worldwide. In the year 2008 approximately 1.38 million new cases were diagnosed, and 458,400 females died from this malignancy [1]. The majority of these tumors are sporadic while five to $10 \%$ are hereditary, and significant proportion of them is due to the inherited mutations either in the BRCA1 or BRCA2 gene [2,3]. There is a strong correlation between the presence of mutations in the BRCA1/2 gene and morphology of the breast cancer. The triple-negative (TN) morphology of breast tumor is found in the $57 \%$ of patients with the $B R C A 1$ gene mutations and $23 \%$ of patients with the $B R C A 2$ gene mutations [4]. TN breast cancers are referred

\footnotetext{
* Correspondence: dagnija.kalniete@rsu.Iv

'Institute of Oncology, Riga Stradins University, Dzirciema Street 16, Riga LV-1007, Latvia

Full list of author information is available at the end of the article
}

to estrogen receptor (ER) negative, progesterone receptor (PR) negative, and human epidermal growth factor receptor (HER2) negative tumors and they have tendency to be more aggressive than other subtypes $[5,6]$. TN breast cancer patients harboring the BRCA1 mutations at the time of the diagnosis are younger, have smaller tumor size, and have significantly better recurrence-free and diseasespecific survival than $\mathrm{TN}$ breast cancer patients with no mutations in the BRCA1 gene [7-10].

MiRNAs are non-coding small RNA molecules that have the ability to regulate gene expression posttranscriptionally, and are involved in the cell differentiation, growth, and apoptosis [11,12]. In tumors, miRNA expression is changed, and there is a correlation between the changed expression and clinical features of the disease $[13,14]$. MiRNAs can act either as tumor inducers or tumor suppressors, and either are up-regulated or down-regulated [15]. One of the most studied tumor 
inducing miRNA which consistently is up-regulated in different types of malignancies, including breast cancer, is miR-21 $[14,16,17]$. By inhibiting the tumor suppressor tropomyosin-1 gene (TPM1) and programmed cell death gene-4 (PDCD4), it is directly involved in the growth, proliferation, and invasion of the tumor cells $[18,19]$. Another target of miR-21 is phosphatase and tensin homolog gene (PTEN) that is involved in the PI3K/Akt pathway [20-22]. In glioblastoma cells, miR-21 targets genes that are involved in the major cancer suppression pathways: in 553 pathway (JMY, TOPORS, IGFBP3, TP53PP2, DAXX, $H N R P K$, and TP73L), in TGF- $\beta$ pathway (TGFFBR2/3, $B H P K 2$, and $D A X X)$, in mitochondrial apoptotic pathway (APAF1 and PPIF) [23]. In breast cancer, the up-regulation of this miRNA is associated with later clinical stage, higher proliferation index $\mathrm{Ki}-67$, and poor prognosis for the patient $[14,17]$. Breast cancer patients with tumor size more than two centimeters have significantly higher expression of miR-21 compared to those with tumor size less than two centimeters [24]. Another oncogenic miRNA which over-expression is associated with breast cancer is miR10b. MiR-10b is involved in the Rhoc-Akt signaling pathway; Rhoc-Akt pathway is suppressed by the repression of HOXD10 thus promoting cancer cell invasion [25]. Moreover, breast cancer patients with tumor size greater than two centimeters have higher miR-10b expression than those with tumor size less than two centimeters [24]. In ovary cancers, miR-214 is expressed differently between the carriers of the BRCA1 gene mutations and noncarriers; miR-214 is down-regulated in the patients with mutations in the BRCA1 gene [26]. One of the targets that miR-214 regulate is PTEN gene; in the EGFR mutated non-small lung tumor cell lines up-regulated miR-214 through the PTEN/AKT pathway induces resistance to gefitinib [27].

Some of the miRNAs have shown different expressions not only within the specific subtype of breast cancer but among distinct subtypes of breast cancer, as well. MiR210 is differently expressed between TN and ER positive/HER2 negative breast cancers: higher expression is in TN breast cancers than in ER positive/HER2 negative breast cancers [28]. A non-significant tendency of high expression level of miR-210 and other miRNAs (miR-21, miR-221, and miR-222) is related to worse overall and disease-free survival of TN breast cancer patients [29]. In another study, TN patients with high expression of miR-210 showed considerably worse overall and diseasefree survival than those with low expression of miR-210 [28]. In contrast, breast cancer patients with negative expression of miR-34b have worse overall and disease-free survival compared to those with positive expression of miR-34b [30].

The aim of this study was to look for the miRNA that differs in expression between TN hereditary and sporadic tumors and associate expression level of some miRNA to disease specific survival of TN breast cancer patients.

\section{Material and methods}

Eighteen TN breast cancer patients harboring the BRCA1 gene mutations and 32 triple-negative sporadic breast cancer patients hospitalized at Pauls Stradins Clinical University Hospital and/or Latvian Oncology Center from 2004 to 2011 were involved in this study. All patients signed informed consent forms.

The BRCA1 gene mutations (5382insC, 4153delA, and C61G) were determined by multiplex polymerase chain reaction [31]. Breast cancer patients with the BRCA1 gene mutations were defined as hereditary [31].

TN tumors were defined as ER and PR 0\% and HER2 protein $0 \%$. This study included only those TN tumor tissues which tumor cell content per specimen was more than 50\%. All histological data was reviewed and evaluated by pathologist. Immunohistochemistry data was analyzed and interpreted by pathologist.

MiRNAs were isolated from the formalin-fixed and paraffin embedded tumor tissues with the RecoverAll Total Nucleic Acid Isolation Kit (Ambion, Applied Biosystems). Reaction of the reverse transcription was done with the TaqMan MicroRNA Reverse Transcription Kit (Applied Biosystems) on the TProfessional Thermal Cycler (Biometra). Quantitative analysis of miRNAs was performed with real-time PCR (Rotor-Gene 6000, Corbett) using TaqMan MicroRNA Assays (Applied Biosystems). Each sample was performed in three repeats. The expression levels were analyzed with the Rotor-Gene Q Series Software 1.7 using comparative quantitation analysis. Each miRNA was normalized by the internal reference RNU6B.

The disease-specific survival was evaluated from the date of the diagnosis till the date of the death from the malignancy. The disease-specific survival was analyzed using the Log-rank (Mantel-Cox) test. The level of the statistical significance was set at the 95\%. The median follow-up period of the TN breast cancer patients was 40 months. According to the American Joint Committee on Cancer (AJCC), as a $\mathrm{T}_{1} / \mathrm{T}_{2}$ group were defined tumors that were $\leq 20 \mathrm{~mm}$ to $\leq 50 \mathrm{~mm}$ in dimension. $\mathrm{T}_{3} / \mathrm{T}_{4}$ group were defined tumors that were $>50 \mathrm{~mm}$ in dimension to any size with direct extension to the chest wall and/or to the skin [AJCC]. Whitney-Mann test was used to calculate miRNA expression differences between TN-H and TN-S tumor tissues. Clinical and pathological characteristics between the BRCA1 gene mutation carriers and non-carriers were compared by $t$-test and Fisher's exact test.

\section{Results}

TN breast cancer patients with the $B R C A 1$ gene mutations at the time of the diagnosis were younger than 
sporadic individuals $(\mathrm{p}=0.0648)$. Higher frequency of TN patients with staging $T_{3}$ were in sporadic group than in hereditary one $(p=0.0731)$. Between hereditary breast cancer patients stage I was more frequent than between sporadic ones $(p=0.0889)$. Medullary carcinomas were significantly more in hereditary group comparing to sporadic one $(\mathrm{p}=0.0442)$ (Table 1$)$.

Association between the median \pm standard deviation expression of each miRNA and $T$ stages $\left(T_{1 / 2}\right.$ and $\left.T_{3 / 4}\right)$ was explored. Statistically not quite a significant difference

Table 1 Clinical and pathological characteristics of BRCA1 mutation carriers $(n=18)$ and non-carriers $(n=32)$

\begin{tabular}{|c|c|c|c|}
\hline Characteristics & $\begin{array}{l}\text { BRCA1 } \\
\text { mutation } \\
\text { carriers, } \\
\mathrm{n}(\%)\end{array}$ & $\begin{array}{l}\text { BRCA1 } \\
\text { mutation } \\
\text { non-carriers, } \\
\mathrm{n}(\%)\end{array}$ & P-value \\
\hline \multicolumn{4}{|l|}{ Age at diagnosis, years } \\
\hline Median & 46 & 55 & 0.0648 \\
\hline Range & $27-72$ & $28-78$ & \\
\hline \multicolumn{4}{|l|}{ T stage } \\
\hline $\mathrm{T}_{1}$ & 7 (38.89) & $6(18.75)$ & 0.1797 \\
\hline $\mathrm{T}_{2}$ & 7 (38.89) & $15(46.88)$ & 0.7676 \\
\hline$T_{3}$ & $1(5.56)$ & $9(28.13)$ & 0.0731 \\
\hline $\mathrm{T}_{4}$ & $3(16.67)$ & $2(6.25)$ & 0.3363 \\
\hline \multicolumn{4}{|l|}{ Nodal status } \\
\hline $\mathrm{N}_{0}$ & $12(66.67)$ & $19(59.38)$ & 0.7637 \\
\hline$N_{1}$ & $0(0.00)$ & $4(12.50)$ & 0.2828 \\
\hline $\mathrm{N}_{2}$ & $5(27.28)$ & $6(18.75)$ & 0.4944 \\
\hline $\mathrm{N}_{3}$ & $1(5.56)$ & $3(9.38)$ & 0.9999 \\
\hline \multicolumn{4}{|l|}{ Metastasis } \\
\hline$M_{0}$ & $17(94.44)$ & $31(96.88)$ & 0.9999 \\
\hline$M_{1}$ & $1(5.56)$ & $1(3.13)$ & 0.9999 \\
\hline \multicolumn{4}{|l|}{ Stage } \\
\hline I & 7 (38.89) & $5(15.63)$ & 0.0889 \\
\hline$\|$ & $5(27.78)$ & $14(43.75)$ & 0.3659 \\
\hline III & $5(27.78)$ & $12(37.50)$ & 0.5482 \\
\hline IV & $1(5.56)$ & $1(3.13)$ & 0.9999 \\
\hline \multicolumn{4}{|l|}{ Histology } \\
\hline Ductal carcinoma & $14(77.78)$ & $28(87.50)$ & 0.3984 \\
\hline Tubular carcinoma & $0(0.00)$ & $1(3.13)$ & 0.9999 \\
\hline Medullary carcinoma & $3(16.67)$ & $0(0.00)$ & 0.0442 \\
\hline Papillary carcinoma & $1(5.56)$ & $2(6.25)$ & 0.9999 \\
\hline No data & $0(0.00)$ & $1(3.13)$ & \\
\hline \multicolumn{4}{|l|}{ Tumor grade } \\
\hline Moderately differentiated & $3(16.67)$ & $1(3.13)$ & 0.1142 \\
\hline Poorly differentiated & $12(66.67)$ & $27(84.38)$ & 0.1142 \\
\hline No data & $3(16.67)$ & $4(12.50)$ & \\
\hline Ki-67 & 73 & 70 & 0.6494 \\
\hline
\end{tabular}

between $T_{1 / 2}$ and $T_{3 / 4}$ groups in the case of miR-31 was observed $(\mathrm{p}=0.0666)$ (Table 2).

The expression level of miR-10b, miR-21, miR-29a, miR-31, and miR-214 in $18 \mathrm{TN}-\mathrm{H}$ and $32 \mathrm{TN}-\mathrm{S}$ breast tumors was analyzed. Measurements were normalized to internal control RNU6B. After normalization outliers were excluded. The median expression level \pm interquartile range (Q1; Q3) of miR-10b, miR-21, miR-29a, miR-31, and miR-214 in TN-H cancer tissues was $0.275 \pm$ 0.287 (0.122; 0.408$), 5.725 \pm 4.250$ (2.408; 6.658), $1.330 \pm$ $1.552(0.478 ; 2.030), 0.254 \pm 0.642(0.041 ; 0.684)$, and $0.489 \pm 1.027(0.350 ; 1.378)$, respectively. The median expression level \pm interquartile range (Q1; Q3) of miR-10b, miR-21, miR-29a, miR-31, and miR-214 in TN-S breast cancer tissues was $0.330 \pm 0.381(0.249 ; 0.631), 9.580 \pm$ 7.545 (5.405; 12.950), $1.490 \pm 0.990$ (1.180; 2.170), $0.592 \pm$ 0.487 (0.332; 0.819 ), and $1.800 \pm 1.250$ (1.170; 2.420), respectively. MiR-214 showed significantly higher expression level in TN-S tumor tissues than in TN-H ones (Figure 1).

Disease-specific survival of the TN breast cancer patients in respect of high and low levels of miR-10b, miR21, miR-31, and miR-214 was analyzed. High and low expression levels were defined as values above and below median expression level, respectively. The median expression \pm interquartile range $(\mathrm{Q} 1 ; \mathrm{Q} 3)$ of $\mathrm{miR}-10 \mathrm{~b}, \mathrm{miR}-21$, miR-31, and miR-214 was $0.327 \pm 0.337$ (0.198; 0.535), $6.990 \pm 9.245$ (3.105; 12.350), $0.488 \pm 0.599$ (0.214; 0.813), and $1.455 \pm 1.593(0.625 ; 2.218)$, respectively. TN breast cancer patients with high expression level of miR-214 showed significantly worse disease-free survival than patients with low expression of this miRNA (Figure 2).

\section{Discussion}

In this study, the $B R C A 1$ gene mutation carriers at the time of the diagnosis were younger than patients with no evadable changes in the $B R C A 1$ gene. Finding is consistent with other studies; the BRCA1 gene mutation carriers at the time of the diagnosis were younger than sporadic breast cancer patients [8]. Medullary carcinomas were seen more in BRCA1 carriers than noncarriers. There has been observed a weak correlation between $B R C A 1$ mutation status and medullar histology of breast cancer [32,33].

Table 2 Association between expression level of each miRNA and $T$ stage

\begin{tabular}{llll}
\hline miRNA & $\mathbf{T}_{\mathbf{1} / \mathbf{2} \pm \text { SD }}$ & $\mathbf{T}_{\mathbf{3} / \mathbf{4} \pm \mathbf{S D}}$ & P-value \\
\hline miR-10b & $0.289 \pm 0.288$ & $0.421 \pm 0.210$ & 0.1411 \\
miR-21 & $6.180 \pm 5.736$ & $7.910 \pm 4.554$ & 0.3093 \\
miR-29a & $1.475 \pm 1.089$ & $1.825 \pm 0.983$ & 0.3399 \\
miR-31 & $0.299 \pm 0.493$ & $0.592 \pm 0.472$ & 0.0666 \\
miR-214 & $1.230 \pm 1.95$ & $1.700 \pm 0.856$ & 0.3775 \\
\hline
\end{tabular}



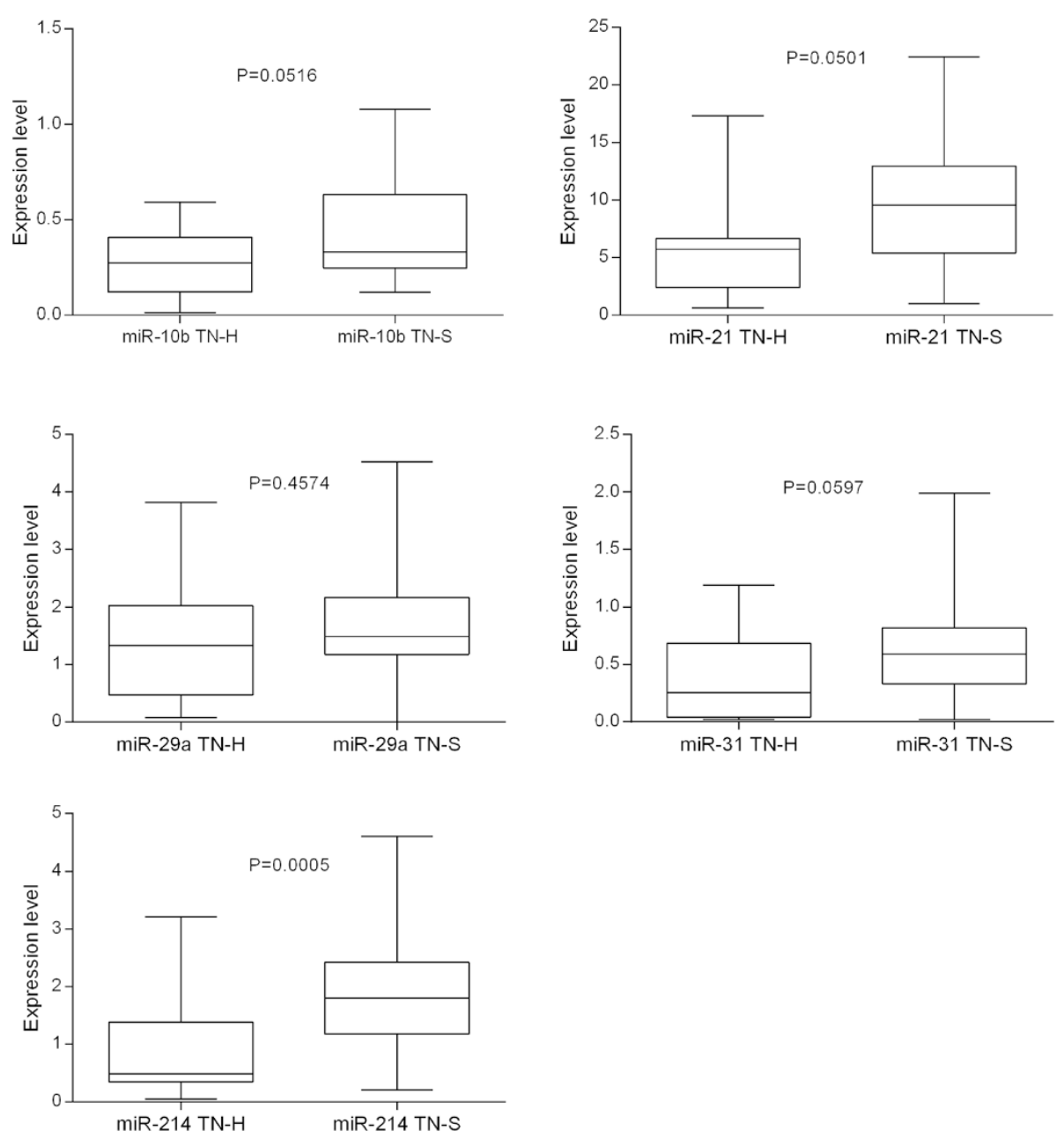

Figure 1 Different miRNA expression between TN-H and TN-S breast cancer tissues. Statistical significance was set at the $95 \%$ level.

TN sporadic breast cancer tissues showed significantly higher expression level of miR-214 than TN hereditary individuals that are consistent with the finding in other study; miR-214 is expressed differentially in ovary cancer patients with and without the BRCA1 gene mutations [26]. High grade serous carcinoma patients with any loss within the BRCA1 gene show lower expression of miR214 than patients with no change [26]. The diseasespecific survival in respect of high and low expression level of miR-214 was analyzed. TN breast cancer patients with high expression level of miR-214 have significantly worse disease-specific survival than patients with low expression of miR-214. According to the results of this study, in the breast cancer, miR-214 may act similarly as oncogene that is consistent with the finding in other study. MiR-214 is up-regulated in preoperative serum samples of breast cancer patients; whereas, in post-operative serum samples, it is decreased and increased miR-214 correlates with positive lymph node status [34]. MiR-214 plays an important role not only in the ovary cancer but as well in the breast cancer development. It is not clear how BRCA1 dysfunction can influence the level of miR-214 in ovarian and breast tumors as yet. It is known that miR-214 targets the PTEN gene; by targeting PTEN Akt pathway is activated thus resulting in the cell survival [35]. In many different types of cancers, in about $40 \%$ of ovarian and breast cancers, Akt kinase activity has been detected increased [36].

In advanced (metastatic) breast cancers, expression of miR-10b is up-regulated as compared to the primary ones [36]. MiR-10b is directly involved in the suppression of the HOXD10 that in turn activates expression of the pro-metastatic gene RHOC [36]. MiR-10b correlation between tumor size, histological grade, clinical stage, positive lymph node status, and HER2 expression is positive [37]. While the correlation between high expression of miR-10b and HER2 expression is positive; the correlation between miR-10b expression and PR and ER status is negative [37]. Over-expression of miR-10b* is associated with reduced disease-free, relapse-free, and 

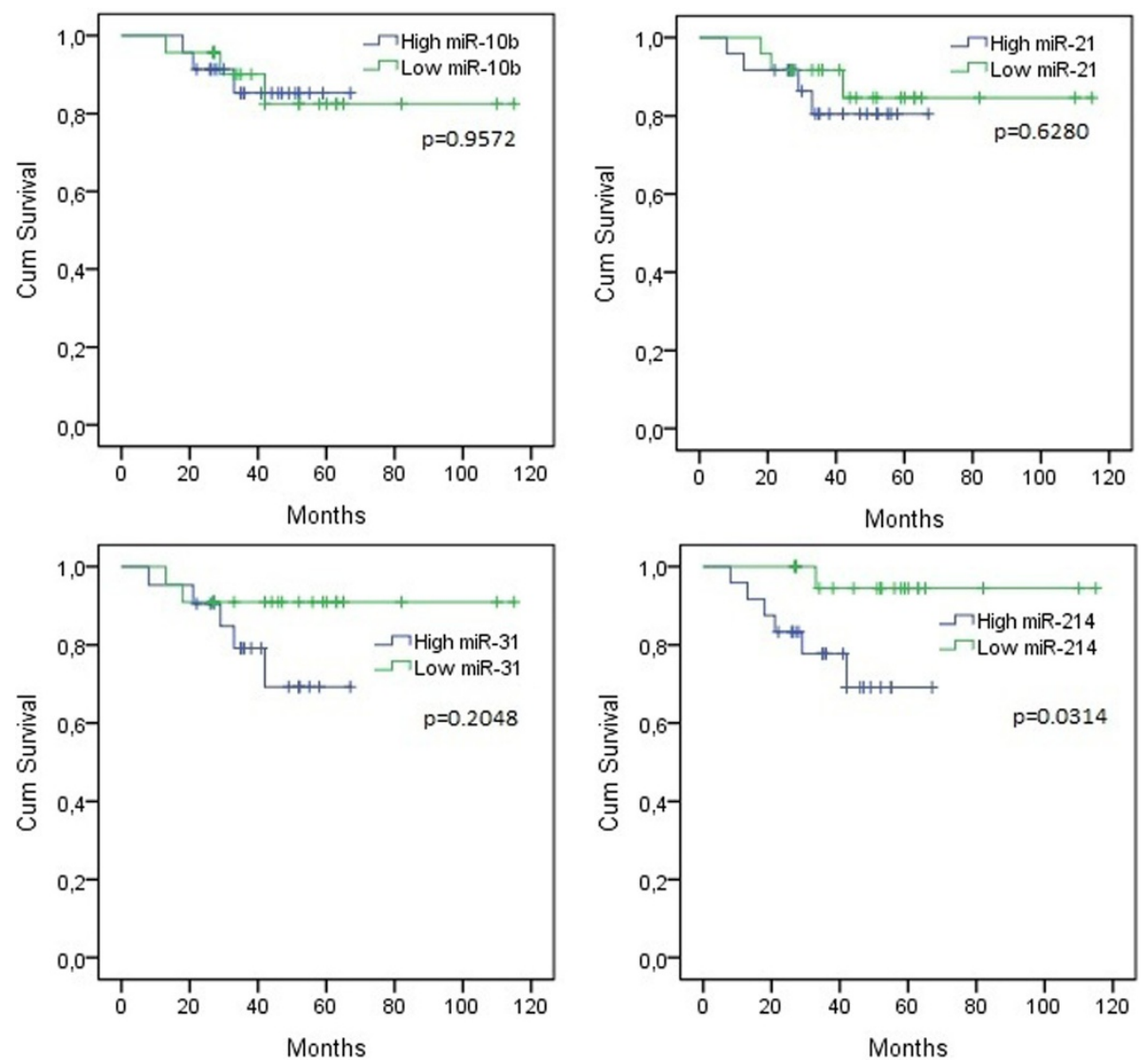

Figure 2 Disease-specific survivals of TN breast cancer patients in regard of high and low expression of miRNAs. Statistical significance was set at the $95 \%$ level.

metastasis-free survivals, compared to those with low expression level [38]. TN-S breast cancer tissues have higher expression level of miR-10b than TN-H ones, though the difference is not quite statistically significant. In addition, the frequency of $\mathrm{T}_{3}$ is higher in sporadic group than in hereditary one. The TN hereditary breast cancer patients at the time of diagnosis have smaller tumor size than sporadic ones [7-9]. A non-significant higher frequency of $\mathrm{T}_{3}$ in sporadic group suggests that sporadic breast cancer patients have higher frequency of tumors that are greater than $5 \mathrm{~cm}$ across than hereditary ones. Moreover, the frequency of stage I among hereditary breast cancer patients is higher than between sporadic breast cancer patients. Findings in this study support findings in other studies.

Another miRNA that in this study was up-regulated in TN-S tissues as compared to TN-H ones was miR-21. As well as in this case, difference between groups was not quite statistically significant. MiR-21 is up-regulated in TN primary breast cancers as compared to healthy breast tissues [29]. Expression of miR-21 is significantly higher in ER $\alpha$ positive, ErbB2 negative, and PR positive than in ER $\alpha$ negative, ErbB2 positive, and PR negative breast cancers [16]. MiR-21 is regulated by both ER $(E R \alpha$ and $E R \beta)$ receptors. Interaction between estradiol (E2) and one of the two ER receptors leads to the inhibition of miR-21 expression thus resulting in a loss of suppression of PDCD4, PTEN and BCL2 protein expression [39]. In addition, interaction between E2 and ER $\alpha$ directly increases transcription of BCL2 [39]. The mRNA profiling analysis revealed that in the adjacent normal breast tissues compared to TN ones, oncogenic BCL2 is down-regulated whereas miR-21 in TN breast cancer tissues is over-expressed [40]. Breast cancer patients with ER negative and PR negative receptor status have significantly higher expression of miR-21 than breast cancer patients with ER positive and PR positive receptor status [24]. TN breast cancer patients with high expression level of miR21 have a non-significant tendency of worse overall and disease-free survival than to those with low expression of miR-21 [29].

In this study higher expression level of miR-31 was in TN-S tumor tissues than in TN-H ones; however, as well in this case the difference was not quite statistically significant. Up-regulation of miR-31 is associated with less aggressive breast cancer subtypes, like luminal ones; 
whereas down-regulation is associated with more aggressive breast cancer subtypes, like triple-negative ones. In the MDA-MB-231 (triple-negative breast cancer subtype) cell lines miR-31 is found down-regulated whereas in the MCF7 (luminal breast cancer subtype) cell lines up-regulated $[41,42]$.

\section{Conclusions}

According to the results of this study miR-214 is an indicator for the TN breast cancer patient's poor prognosis and possibly could be used as a potential prognostic biomarker for TN breast cancer subtype.

\section{Competing interests}

The authors declare that they have no competing interests.

\section{Authors' contributions}

DK carried out the molecular genetic studies, interpreted data, performed statistical analysis, and drafted the manuscript. MNM participated in the molecular genetic studies, assisted in the statistical analysis, and was involved in the drafting of the manuscript. IŠ performed immunohistochemistry analysis and interpreted pathological data. AĀ performed immunohistochemistry analysis and interpreted pathological data. Al assisted in the interpretation of the clinical data and assisted in the drafting of the manuscript. JG assisted in the drafting of the manuscript. EM participated in the design and coordination of the study, and was involved in the drafting of the manuscript, and gave final approval. All authors read and approved the final manuscript.

\section{Acknowledgments}

This study has been supported by the European Social Fund co-financed project: "Creation of a new interdisciplinary research team to investigate breast cancer and to increase the efficacy of therapy and the patient's quality of life", agreement No. 2009/0230/1.1.1.2.0/09/APIANIAA/070.

\section{Author details}

'Institute of Oncology, Riga Stradins University, Dzirciema Street 16, Riga LV-1007, Latvia. ${ }^{2}$ Breast Disease Center, Pauls Stradins Clinical University Hospital, Pilsonu Street 13, Riga LV-1002, Latvia.

\section{Received: 7 April 2014 Accepted: 20 January 2015}

\section{Published online: 08 February 2015}

\section{References}

1. Jemal A, Bray F, Center MM, Ferlay J, Ward E, Forman D. Global cancer statistics. CA Cancer J Clin. 2011;61(2):69-90.

2. Claus EB, Schildkraut JM, Thompson WD, Risch NJ. The genetic attributable risk of breast and ovarian cancer. Cancer. 1996;77(11):2318-24.

3. Thompson D, Easton D. The genetic epidemiology of breast cancer genes. J Mammary Gland Biol Neoplasia. 2004;9(3):221-36.

4. Atchley DP, Albarracin CT, Lopez A, Valero V, Amos Cl, Gonzalez-Angulo AM, et al. Clinical and pathologic characteristics of patients with BRCA-positive and BRCA-negative breast cancer. J Clin Oncol. 2008;26:4282-8.

5. Perou CM, Sørlie T, Eisen MB, van de Rijn M, Jeffery SS, Rees CA, et al. Molecular portraits of human breast tumours. Nature. 2000;406(6797):747-52.

6. Dent R, Trudeau M, Pritchard Kl, Hanna WM, Kahn HK, Sawka CA, et al. Triple-negative breast cancer: clinical features and patterns of recurrence. Clin Cancer Res. 2007;13:4429-34.

7. Bayraktar S, Gutierrez-Barrera AM, Liu D, Tasbas T, Akar U, Litton JK, et al. Outcome of triple-negative breast cancer in patients with or without deleterious BRCA mutations. Breast Cancer Res Treat. 2011;130(1):145-53.

8. Gonzalez-Angulo AM, Timms KM, Liu S, Chen H, Litton JK, Potter J, et al. Incidence and outcome of BRCA mutations in unselected patients with triple-negative breast cancer. Clin Cancer Res. 2011;17(5):1082-9.

9. Lee L, Alexander B, Schnitt SJ, Comander A, Gallagher B, Garber JE, et al. Clinical outcome of triple negative breast cancer in BRCA1 mutation carriers and noncarriers. Cancer. 2011;117(14):3093-100.
10. Maksimenko J, Irmejs A, Nakazawa-Miklasevica M, Melbarde-Gorkusa I, Trofimovics G, Gardovskis J, et al. Prognostic role of BRCA1 mutation in patients with triple-negative breast cancer. Oncol Lett. 2014;7(1):278-84.

11. Cannell IG, Kong YW, Bushell M. How do microRNAs regulate gene expression? Biochem Soc Trans. 2008;36:1224-31.

12. Calin GA, Dumitru CD, Shimizu M, Bichi R, Zupo S, Noch E, et al. Frequent deletions and down-regulation of micro-RNA genes miR15 and miR16 at $13 q 14$ in chronic lymphocytic leukemia. Proc Natl Acad Sci U S A. 2002;99(24):15524-9.

13. Iorio MV, Ferracin M, Liu CG, Veronese A, Spizzo R, Sabbioni S, et al. MicroRNA gene expression deregulation in human breast cancer. Cancer Res. 2005;65(16):7065-70.

14. Yan $L X$, Huang XF, Shao Q, Huang MY, Deng L, Wu QL, et al. MicroRNA miR21 overexpression in human breast cancer is associated with advanced clinical stage, lymph node metastasis and patient poor prognosis. RNA. 2008;14(11):2348-60.

15. Heneghan HM, Miller N, Lowery AJ, Sweeney K, Kerin MJ. MicroRNAs as novel biomarkers for breast cancer. J Oncol. 2010;2010:1-7.

16. Mattie MD, Benz CC, Bowers J, Sensinger K, Wong L, Scott GK, et al. Optimized high-throughput microRNA expression profiling provides novel biomarker assessment of clinical prostate and breast cancer biopsies. Mol Cancer. 2006;5:24.

17. Huang GL, Zhang XH, Guo GL, Huang KT, Yang KY, Shen X, et al. Clinical significance of miR-21 expression in breast cancer: SYBR-Green I-based real-time RT-PCR study of invasive ductal carcinoma. Oncol Rep. 2009;21(3):673-9.

18. Zhu S, Si ML, Wu H, Mo YY. MicroRNA-21 targets the tumor suppresor gene tropomyosin 1 (TPM1). J Biol Chem. 2007;282(19):14328-36.

19. Frankel LB, Christoffersen NR, Jacobsen A, Lindow M, Krogh A, Lund AH. Programmed cell death 4 (PDCD4) is an important functional target of the microRNA miR-21 in breast cancer cells. J Biol Chem. 2008;283(2):1026-33.

20. Li LQ, Li XL, Wang L, Du WJ, Guo R, Liang HH, et al. Matrine inhibits breast cancer growth via miR-21/PTEN/Akt pathway in MCF-7 cells. Cell Physiol Biochem. 2012;30(3):631-41.

21. Zhang JG, Wang JJ, Zhao F, Liu Q, Jiang K, Yang GH. MicroRNA-21 (miR-21) represses tumor suppressor PTEN and promotes growth and invasion in non-small cell lung cancer (NSCLC). Clin Chim Acta. 2010;411:846-52.

22. Carnero A, Blanco-Aparicio C, Renner O, Link W, Leal JF. The PTEN/PI3K/AKT signalling pathway in cancer, therapeutic implications. Curr Cancer Drug Targets. 2008;8(3):187-98.

23. Papagiannakopoulos T, Shapiro A, Kosik KS. MicroRNA-21 targets a network of key tumor-suppressive pathways in glioblastoma cells. Cancer Res. 2008;68(19):8164-72.

24. Hafez MM, Hassan ZK, Zekri AR, Gaber AA, Al Rejaie SS, Sayed-Ahmed MM, et al. MicroRNAs and metastasis-related gene expression in Egyptian breast cancer patients. Asian Pac J Cancer Prev. 2012;13(2):591-8.

25. Liu Z, Zhu L, Cao H, Ren H, Fang X. miR-10b promotes cell invasion through RhoC-AKT signaling pathway by targeting HOXD10 in gastric cancer. Int J Oncol. 2012;40(5):1553-60.

26. Lee CH, Subramanian S, Beck AH, Espinosa I, Senz J, Zhu SX, et al. MicroRNA profiling of BRCA1/2 mutation-carrying and non-mutationcarrying high-grade serous carcinomas of ovary. PLoS One. 2009;4(10):e7314.

27. Wang YS, Wang YH, Xia HP, Zhou SW, Schmid-Bindert G, Zhou CC. MicroRNA-214 regulates the acquired resistance to gefitinib via the PTEN/AKT pathway in EGFR-mutant cell lines. Asian Pac J Cancer Prev. 2012;13(1):255-60.

28. Toyama T, Kondo N, Endo Y, Sugiura H, Yoshimoto N, Iwasa M, et al. High expression of microRNA-210 is an independent factor indicating a poor prognosis in Japanese triple-negative breast cancer patients. Jpn J Clin Oncol. 2012;42(4):256-63.

29. Radojicic J, Zaravinos A, Vrekoussis T, Kafousi M, Spandidos DA, Stathopoulos EN. MicroRNA expression analysis in triple negative (ER, PR and Her2/neu) breast cancer. Cell Cycle. 2011;10(3):507-17.

30. Svoboda M, Sana J, Redova M, Palacova M, Fabiana P, Slaby O, et al. MiR$34 \mathrm{~b}$ is associated with clinical outcome in triple-negative breast cancer patients. Diagn Pathol. 2012;7:31.

31. Berzina D, Nakazawa-Miklasevica M, Zestkova J, Aksenoka K, Irmejs A, Gardovskis A, et al. BRCA1/2 mutation screening in high-risk breast/ovarian cancer families and sporadic cancer patient surveilling for hidden high-risk families. BMC Med Genet. 2013;14:61.

32. Eisinger F, Jacquemier J, Charpin C, Stoppa-Lyonnet D, Bressac-de Paillerets B, Peyrat JP, et al. Mutations at BRCA1: the medullary breast carcinoma revisited. Cancer Res. 1998;58(8):1588-92. 
33. lau PT, Marafie M, Ali A, Sng JH, Macmillan RD, Pinder S, et al. Are medullary breast cancers an indication for BRCA1 mutation screening? A mutation analysis of 42 cases of medullary breast cancer. Breast Cancer Res Treat. 2004;85(1):81-8.

34. Schwarzenbach $H$, Milde-Langosch K, Steinbach B, Muller V, Pantel K. Diagnostic potential of PTEN-targeting miR-214 in the blood of breast cancer patients. Breast Cancer Res Treat. 2012;134(3):933-41.

35. Yang $H$, Kong W, He L, Zhao JJ, O'Donnell JD, Wang J, et al. MicroRNA expression profiling in human ovarian cancer: miR-214 induces cell survival and cisplatin resistance by targeting PTEN. Cancer Res. 2008;68(2):425-33.

36. Ma L, Teruya-Feldstein J, Weinberg RA. Tumor invasion and metastasis initiated by microRNA-10b in breast cancer. Nature. 2007;449(7163):682-8.

37. Liu Y, Zhao J, Zhang PY, Zhang Y, Sun SY, Yu SY, et al. MicroRNA-10b targets E-cadherin and modulates breast cancer metastasis. Med Sci Monit. 2012;18 (8):BR299-308.

38. Biagioni F, Bossel Ben-Moshe N, Fontemaggi G, Canu V, Mori F, Antoniani B, et al. miR-10b*, a master inhibitor of the cell cycle, is down-regulated in human breast tumours. EMBO. Mol Med. 2012;4(11):1214-29.

39. Wickramasinghe NS, Manavalan TT, Dougherty SM, Riggs KA, Li Y, Klinge CM. Estradiol downregulates miR-21 expression and increases miR-21 target gene expression in MCF-7 breast cancer cells. Nucleic Acids Res. 2009;37(8):2584-95.

40. Cascione L, Gasparini P, Lovat F, Carasi S, Pulvirenti A, Ferro A, et al. Integrated microRNA and mRNA signatures associated with survival in triple negative breast cancer. PLoS One. 2013;8(2):e55910.

41. Sossey-Alaoui K, Downs-Kelly E, Das M, Izem L, Tubbs R, Plow EF. WAVE3, an actin remodeling protein, is regulated by the metastasis suppressor microRNA, miR-31, during the invasion-metastasis cascade. Int J Cancer. 2011;129(6):1331-43.

42. Augoff K, McCue B, Plow EF, Sossey- Alaoui K. miR-31 and its host gene IncRNA LOC554202 are regulated by promoter hypermethylation in triplenegative breast cancer. Mol Cancer. 2012;11:5.

\section{Submit your next manuscript to BioMed Central and take full advantage of:}

- Convenient online submission

- Thorough peer review

- No space constraints or color figure charges

- Immediate publication on acceptance

- Inclusion in PubMed, CAS, Scopus and Google Scholar

- Research which is freely available for redistribution 